\title{
ANTIBACTERIAL, IN VITRO CYTOTOXIC, AND ANTIOXIDANT ACTIVITIES OF ELECTROLYZED OXIDIZING/REDUCING WATER
}

\author{
ASMIYENTI DJALIASRIN DJALIL ${ }^{1 *}$, ELZA SUNDHANI ${ }^{1}$, RETNO WAHYUNINGRUM ${ }^{1}$, DWI HARTANTI ${ }^{1}$, \\ NONI LESTIOWATI ${ }^{1}$, PRAYOGO PANGESTU ${ }^{1}$, RIDWAN SETIAJI ${ }^{1}$, SUWANDRI SUWANDRI ${ }^{2}$
}

${ }^{1}$ Department of Pharmacy, Faculty of Pharmacy, Universitas Muhammadiyah Purwokerto, Jl. Raya Dukuhwaluh, P0. Box 202, Purwokerto 53182, Indonesia. ${ }^{2}$ Department of Chemistry, Faculty of Mathematics and Natural Sciences, Universitas Jenderal Soedirman, Jl. Dr. Soeparno, Purwokerto 53123, Indonesia. Email: asmiyentidjaliasrindjalil@ump.ac.id

Received: 10 November 2018, Revised and Accepted: 06 December 2018

ABSTRACT

Objective: Electrolyzed oxidizing/reducing water is popular as health beneficial water in Indonesia. In this study, we examined the level of antibacterial, anticancer, and antioxidant activity of the electrolyzed water.

Methods: The efficacy of electrolyzed water produced by Enagic ${ }^{\circledR}$ at six level pH (2.5, 6.0, 7.0, 8.5, 9.0, and 9.5) was investigated. Antibacterial activity was evaluated using a macrodilution method. The anticancer activity was performed against human breast cancer (T47D) cell lines using 3-(4,5-dimethylthiazol-2-yl)-2,5-diphenyl tetrazolium bromide assay. Moreover, the antioxidant activity was determined using antioxidant model, 2,2-diphenyl-1picrylhydrazyl radical scavenging activity.

Results: The results show that electrolyzed water exhibited antibacterial activity against Propionibacterium acnes and Staphylococcus epidermidis. Among six level pH, electrolyzed water at pH 2.5 showed the highest antibacterial activity. The in vitro cytotoxic activity of electrolyzed water showed potential moderate cytotoxicity. The activity tends to be higher in alkaline electrolyzed water. However, the electrolyzed water showed free radical scavenging activity.

Conclusion: Electrolyzed water that marked in Indonesia has some potential health benefits. The activity is dependent on pH.

Keywords: Antibacterial activity, Antioxidant, Anticancer, Electrolyzed water, A healthy water.

(C) 2019 The Authors. Published by Innovare Academic Sciences Pvt Ltd. This is an open access article under the CC BY license (http://creativecommons. org/licenses/by/4. 0/) DOI: http://dx.doi.org/10.22159/ijap.2019.v11s5.T0043

\section{INTRODUCTION}

Today, people are very concerned about consuming drinks that have some health beneficial effects, including the Indonesian community. The functional water can be obtained by irradiation of light, ultrasonication, treatment with a magnetic field, and electrolysis. Among these methods, electrolyzed water has been widely used for functional water.

Electrolyzed oxidizing/reducing water that has been developed in Japan is one option that has some health beneficial effects. This water is made through an ionization process by flowing electric current, which ultimately produces alkaline and acidic water. The alkaline water or electrolyzed reduced water (ERW) is rich in hydroxyl ions $\left(\mathrm{OH}^{-}\right)$. On the other hand, the acidic water or electrolyzed oxidized water (EOW) is rich in hydrogen ions $\left(\mathrm{H}^{+}\right)$. Its water has advantages because it has smaller molecular cluster compared to its raw material, making it more simply absorbed by the body. Electrolyzed water is made by passing the aqueous solution of $\mathrm{NaCl}$ or $\mathrm{KCl}$ solution on an electrolyzing machine. This machine consists of anodes and cathodes separated by a special diaphragm which separates the alkaline fraction at the cathode and the acid fraction at the anode [1]. The negatively charged particles and ions $\left(\mathrm{Cl}^{-}\right.$and $\left.\mathrm{OH}^{-}\right)$move toward the anode where electrons are released, and hydrochloric acid $(\mathrm{HCl})$, hypochlorous acid $(\mathrm{HOCl})$, hypochlorite ion $\left({ }^{-} \mathrm{OCl}\right)$, oxygen gas $\left(\mathrm{O}_{2}\right)$, and chlorine gas $\left(\mathrm{Cl}_{2}\right)$ are produced. However, positively charged ions and particles $\left(\mathrm{H}^{+}\right.$and $\left.\mathrm{Na}^{+}\right)$move toward the cathode, where they obtain electrons, resulting in the generation of sodium hydroxide $(\mathrm{NaOH})$ and hydrogen gas [2].

Previous studies have shown that EOW effectively kills Escherichia coli, Salmonella enteritidis, and Listeria monocytogenes [3,4]. The electrolyzed water shows bactericidal, virucidal, and fungicidal effects in numerous areas such as medicine and dentistry as well as on fruits, vegetables, and agriculture [2,5]. ERW is known to suppress oxidative stress associated with the disease, such as diabetes [6], cancer [7-10], arteriosclerosis, and neurodegenerative diseases [11]. On the other hand, neutral electrolyzed water has been shown to be effective for the inactivation of human norovirus [12].

One of the most popular electrolyzed water in Indonesia is produced by Enagic. This water is available on the market at various $\mathrm{pH}$ values. The $\mathrm{pH}$ is $2.5,6.0,7.0,8.5,9.0$, and 9.5 with different uses. This research was conducted to determine the electrolyzed water potential for health marked in Indonesia by conducting antibacterial, anticancer, and antioxidant activity tests.

\section{MATERIALS AND METHODS}

\section{Materials}

Water electrolyzed used for this study was purchased from local producers in Indonesia. The water was generated using a water ionization machine made by the Japanese company Enagic. Six different $\mathrm{pH}$ of electrolyzed waters were used in the present research. Human breast cancer T47D cells lines were provided from cancer and stem cells research center, Universitas Muhammadiyah Purwokerto. Propionibacterium acnes and Staphylococcus epidermidis were obtained from the American type culture collection (ATCC; Rockville, MD, USA) as well as the culture collection of the Laboratory Microbiology, Universitas Muhammadiyah Purwokerto. Fetal bovine serum (FBS), Dulbecco's modified eagles medium (DMEM), penicillin-streptomycin, trypsin-EDTA, and fungizone were procured from Gibco (Invitrogen, USA). Phosphate-buffered saline (PBS) 3-[4, 5-dimethylthiazol-2-yl]-2,5 diphenyltetrazolium bromide (MTT), 2,2-diphenyl-1-picrylhydrazyl 
(DPPH), and nutrient agar (NA) were purchased from Sigma-Aldrich. Furthermore, sodium dodecyl sulfate (SDS) and $\mathrm{HCl}$ were obtained from Merck.

\section{Antibacterial activity of electrolyzed water}

Agar macrodilution was adopted for measuring the antibacterial activity of the electrolyzed water. Clindamycin $(20 \mu \mathrm{g} / \mathrm{mL})$ was used as the positive control; however, sterile distilled water was used as a negative control. Electrolyzed waters with different $\mathrm{pH}(2.5,6.0,7.0$, 8.5, 9.0, and 9.5) were collected from Purwokerto, Indonesia. A $1 \mathrm{~mL}$ bacterial inoculum $\left(1 \times 10^{8}\right.$ colony-forming unit $\left.[\mathrm{CFU} / \mathrm{mL}]\right)$ was added to $9 \mathrm{~mL}$ aliquot of each electrolyzed water sample in $15 \mathrm{~mL}$ sterile conical tubes ( 5 tubes per samples). The tubes were incubated at $35^{\circ} \mathrm{C}$ for $6 \mathrm{~min}$. The treatment electrolyzed waters were diluted serially and plated (100 mL per plate) onto NA. Then, agar plates were incubated in an anaerobic environment at $37^{\circ} \mathrm{C}$ for $24 \mathrm{~h}$. After incubation, the colony was counted by colony counter.

\section{In vitro cytotoxic activity of electrolyzed water}

Three different $\mathrm{pH}$ of electrolyzed waters $(2.5,6$, and 9) were used in the experiment. T47D cells are regenerated in the medium when used in vitro tests. T47D cells were grown in DMEM growing media containing FBS $10 \%(\mathrm{v} / \mathrm{v})$ and penicillin-streptomycin $1 \%(\mathrm{v} / \mathrm{v})$. The cells $\left(10^{4}\right.$ cells/well) were planted into the 96 plates and incubated at $37^{\circ} \mathrm{C}$ for $24 \mathrm{~h}$, with $5 \% \mathrm{CO}_{2}$. After incubation, the culture medium was removed and cells were washed using PBS. The cells were treated by electrolyzed water and then incubated again for $24 \mathrm{~h}$. The concentration of each electrolyzed water was $100.0,75.0,50.0,25.0$, and $12.5 \%(\mathrm{v} / \mathrm{v}$ ) in DMEM. Cell viability was determined by MTT assay. The cells were added with MTT-containing medium $(0.5 \mathrm{mg} / \mathrm{mL})$ for $4 \mathrm{~h}$ at $37^{\circ} \mathrm{C}$, with $5 \% \mathrm{CO}_{2}$. Viable cells will react with MTT to generate purple colored formazan crystals. After $4 \mathrm{~h}$ of incubation, the reaction was stopped with $10 \%$ SDS in $0.1 \mathrm{M} \mathrm{HCl}$ solution. Then, the plate was incubated overnight at room temperature and protected from light. At the end of incubation, the plates were shaken, and cells absorbance was measured by ELISA reader (Bio-Rad) at $\lambda 595 \mathrm{~nm}$.

\section{Antioxidant activity of electrolyzed water}

Antioxidant activity of electrolyzed water was determined using the DPPH radical scavenging assay adopted by Brand-Williams et al. [13] with a minor modification. Briefly, the DPPH solution $0.004 \%(\mathrm{w} / \mathrm{v})$ $2 \mathrm{~mL}$ was added on to electrolyzed water in concentration from 6.25 to $100 \%(\mathrm{v} / \mathrm{v})$. The mixture was allowed to stand at room temperature in the dark for $30 \mathrm{~min}$. Then, the absorbance is read at the maximum wavelength. After incubation, the absorbance was measured at $516 \mathrm{~nm}$ against a blank by spectrophotometer Ultraviolet (UV) Vis (Shimadzu UV-1201). The ability to scavenge the DPPH• was determined using the formula given by Brand-Williams et al. [13]. The activities were compared to L-ascorbic acid [14].

\section{RESULTS AND DISCUSSION}

In this research, six different commercially available $\mathrm{pH}$ of electrolyzed water were evaluated by $\mathrm{pH}$ meter (metrohm). These $\mathrm{pH}$ values are shown in Table 1. It can be observed that the $\mathrm{pH}$ values found for samples 2-5 are in close agreement with the labeled $\mathrm{pH}$. Sample 1 presented $\mathrm{pH}$ value above the labeled $\mathrm{pH}$, whereas sample 6 presented $\mathrm{pH}$ value under the labeled $\mathrm{pH}$.

The highest difference of $\mathrm{pH}$ value is in the sample with a $\mathrm{pH}$ label 2.5. Based on data from chemical analysis and spectroscopic data, the main components of electrolyzed acidic water are $\mathrm{Cl}_{2} / \mathrm{HClO}$, which is in equilibrium according to the $\mathrm{pH}$ of the solution $[4,15]$. The $\mathrm{Cl}_{2}$ gas is susceptible to decrease due to the storage; this will cause the $\mathrm{pH}$ of the water to increase.

\section{Antibacterial activity of electrolyzed water}

Antibacterial activity of electrolyzed water was investigated against skin poisoning bacteria, including P. acnes and S. epidermidis. The bacterial cells have been recognized as bacteria initiating inflammation in acne.
It has been claimed that electrolyzed water, especially marked in the strong acid water, can be used to treat infections caused by bacteria on the skin. Clindamycin antibiotics are used as a positive control. The results of electrolyzed water in killing P. acnes and S. epidermidis are reported in Table 2 .

Unlike electrolyzed water at $\mathrm{pH}$ 6.0, 7.0, 8.5, 9.0, and 9.5, the results of the antibacterial activity test against $P$. acnes and $S$. epidermidis at pH 2.5 showed that there were no bacterial colonies growing (Fig. 1). This result is in line with previous studies which indicated that electrolyzed oxidizing water might be potential as a disinfectant [16] This is possible because electrolyzed water at low pH contains a high concentration of $\mathrm{HOCl}$. The concentration of $\mathrm{HOCl}$ is known to correlate with the ability of electrolyzed water to kill bacterial cells [15]. In water with a low $\mathrm{pH}$ can damage the outer membrane of bacterial cells so that $\mathrm{HOCl}$ can enter bacterial cells more efficiently [17]. $\mathrm{HOCl}$ is the most active chlorine compound, apparently killing microbial cells through inhibition of glucose oxidation by chlorine sulfide-oxidizing groups of certain enzymes that are important in carbohydrate metabolism [18].

Table 1: pH measurements of electrolyzed water

\begin{tabular}{llll}
\hline Sample & Labelled $\mathbf{p H}$ & Found $\mathbf{p H}$ & $\mathbf{p H}$ differences \\
\hline 1 & 2.5 & $2.76 \pm 0.04$ & 0.36 \\
2 & 6.0 & $6.03 \pm 0.05$ & 0.03 \\
3 & 7.0 & $7.01 \pm 0.02$ & 0.01 \\
4 & 8.5 & $8.47 \pm 0.04$ & 0.03 \\
5 & 9.0 & $8.99 \pm 0.02$ & 0.01 \\
6 & 9.5 & $9.38 \pm 0.21$ & 0.12 \\
\hline
\end{tabular}

Table 2: Viability of $P$. acnes and $S$. epidermidis after exposure to electrolyzed water measurements of electrolyzed water

\begin{tabular}{lll}
\hline Treatment & CFU $/ \mathbf{m L}$ \\
\cline { 2 - 3 } & P. acnes & S. epidermidis \\
\hline Positive control & $0 \pm 0$ & $0 \pm 0$ \\
pH 2.5 & $0 \pm 0$ & $0 \pm 0$ \\
pH 6.0 & $1420 \pm 148$ & $398 \pm 69$ \\
pH 7.0 & $557 \pm 103$ & $1927 \pm 661$ \\
pH 8.5 & $403 \pm 67$ & $1116 \pm 117$ \\
pH 9.0 & $1168 \pm 175$ & $228 \pm 21$ \\
pH 9.5 & $1503 \pm 122$ & $24 \pm 3$ \\
\hline
\end{tabular}

${ }^{a}$ Mean \pm SD, $n=5$, P. acnes: Propionibacterium acnes, S. epidermidis: Staphylococcus epidermidis, CFU: Colony-forming unit

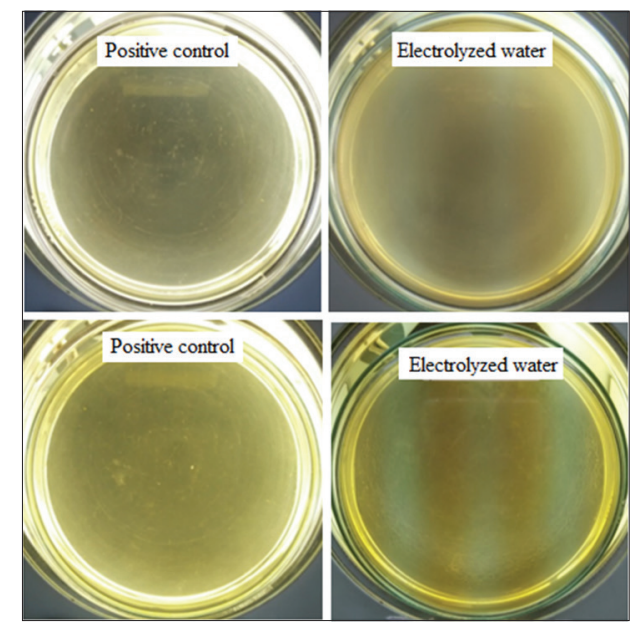

Fig. 1: Effect of electrolyzed water at $\mathrm{pH} 2.5$ on the growth of Propionibacterium acnes (top) and Staphylococcus epidermidis (bottom) by agar macrodilution 
Table 3: Antioxidant activity of electrolyzed water, using DPPH free radical scavenging method

\begin{tabular}{lll}
\hline Treatment & $\mathbf{E C}_{\mathbf{5 0}} \pm \mathbf{S D}(\%)$ & $\mathbf{E C}_{\mathbf{2 0}} \pm \mathbf{S D}(\%)$ \\
\hline pH 2.5 & $227.4 \pm 9.7$ & $102.5 \pm 8.0$ \\
pH 6.0 & $293.0 \pm 34.4$ & $130.3 \pm 16.5$ \\
pH 7.0 & $607.4 \pm 28.7$ & $219.6 \pm 13.1$ \\
pH 8.5 & $195.8 \pm 4.5$ & $63.3 \pm 2.3$ \\
pH 9.0 & $177.4 \pm 1.6$ & $63.2 \pm 4.0$ \\
pH 9.5 & $167.6 \pm 2.8$ & $56.0 \pm 3.2$ \\
Ascorbic acid & $9.3 \pm 0.4(\mu \mathrm{g} / \mathrm{mL})$ & $3.4 \pm 0.3(\mu \mathrm{g} / \mathrm{mL})$ \\
\hline DPPH: 2,2-diphenyl-1picrylhydrazyl, EC $: 50 \%$ efficient concentration
\end{tabular}

P. acnes grew well in neutral or slightly alkaline. This result is in line with previous studies [19]. We observed that $P$. acnes was still survived even at $\mathrm{pH} 9.5$ of electrolyzed water. Furthermore, S. epidermidis grew much better in the $\mathrm{pH}$ of 7.0-8.5. However, minor changes in the $\mathrm{pH}$ in the pH 9.0-9.5 range can decrease the number of S. epidermidis. S. epidermidis did not survive at $\mathrm{pH} 9.5$ of electrolyzed water. A substantial population reduction of $S$. epidermidis at $\mathrm{pH} 9.5(24 \mathrm{CFU} / \mathrm{mL})$ was observed after $24 \mathrm{~h}$ incubation. The reduction population of $S$. epidermidis is known to correlate with the high concentration of $\mathrm{OCl}^{-}$in electrolyzed water at pH 9.0-9.5 [20].

\section{In vitro cytotoxic activity of electrolyzed water}

The in vitro cytotoxic activity of electrolyzed waters with different $\mathrm{pH}$ was evaluated against T47D breast cancer cell. T47D cell is a continuous cell line isolated from ductal breast tumor tissue. This cell expresses the p53 protein, which has a mutation. This causes p53 cannot bind to the response of elements to DNA. Thus, the ability of p53 to regulate cell cycle is reduced and can even remove [21]. The treatment of electrolysis water samples for $24 \mathrm{~h}$ resulted in a decrease in percentage of T47D cell viability compared to cell control (Fig. 2). Under acidic, slightly acidic, and slightly alkaline conditions, electrolyzed waters had in vitro cytotoxic activity. The electrolyzed water at $\mathrm{pH} 2.5$ had the lowest cytotoxicity on T47D cell lines, with an the half maximal inhibitory concentration $\left(\mathrm{IC}_{50}\right.$ ) of $59.4 \%$, followed by electrolyzed water at $\mathrm{pH} 6$ with an $\mathrm{IC}_{50}$ value of $47.0 \%$, and electrolyzed water at $\mathrm{pH} 9$ with an $\mathrm{IC}_{50}$ value of $46.6 \%$.

Morphological alteration of T47D cell lines on exposure using electrolyzed water was demonstrated under an inverted microscope (Carl Zeiss) with a magnification of $\times 20$ (Fig. 3). The cells showed the most noticeable effect after incubation to the electrolyzed water. At high electrolyzed water concentration (100\%), a shrunken and rounder of the cells were conspicuously observed. Most of the cells showed signs of detachment from the surface of the well plates indicating cell death.

\section{Antioxidant activity of electrolyzed water}

The previous study has found that ERW exhibits reactive oxygen species (ROS)-scavenging activity. It can scavenge not only $\mathrm{H}_{2} \mathrm{O}_{2}$ and superoxide radical but also singlet oxygen and hydroxyl radical. ERW has an alkaline $\mathrm{pH}$. In the current study, we actually observed that electrolyzed water can scavenge free radical species not only at alkaline but also at $\mathrm{pH} 2.5$ and 6.0. The DPPH radical scavenging activity results are presented in Table 3 as compared with known antioxidant ascorbic acid.

According to observed experimental data in term of $50 \%$ efficient concentration $\left(\mathrm{EC}_{50}\right)$, unfortunately, we cannot categorize an antioxidant capacity of electrolyzed water regarding Blois's category [22]. A DPPH method could not detect radical-scavenging activity in electrolyzed water sensitively [23]. The intracellular ROS scavenging activity method (fluorescent stain method and immuno-spin trapping assay) and electrochemical techniques seem to be able to observe the activity specifically $[23,24]$.

\section{CONCLUSION}

Some Indonesian people have a positive opinion about electrolyzed water marketed in Indonesia. The water has various $\mathrm{pH}$ with different

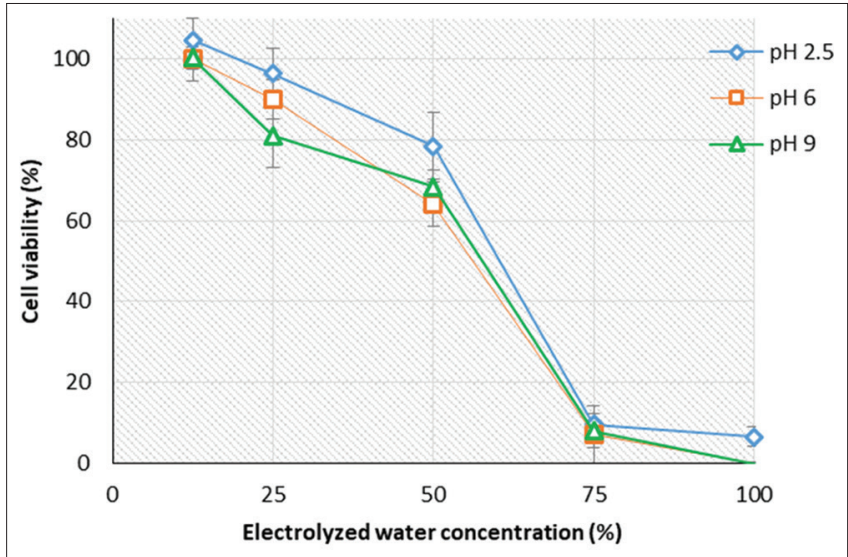

Fig. 2: In vitro cytotoxic activity of electrolyzed water against T47D cell lines

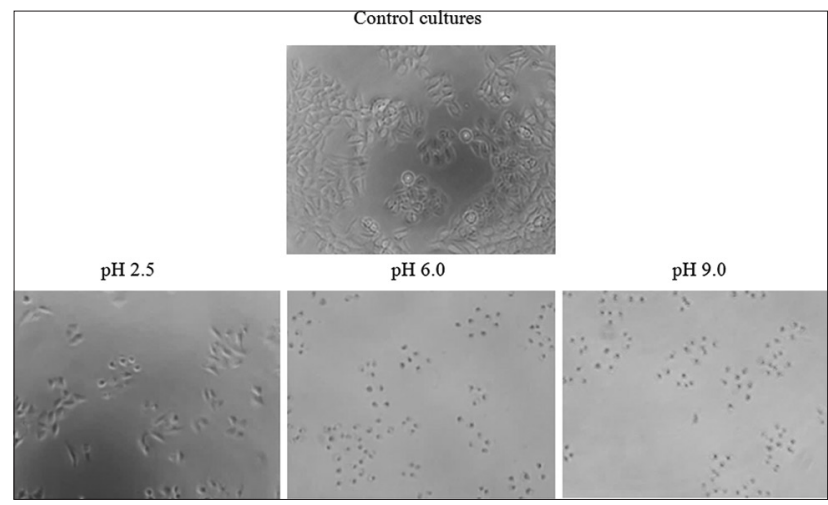

Fig. 3: Phase contrast images of T47D cells after incubation with $100 \%$ of electrolyzed waters at $\mathrm{pH} 2.5,6.0$, and 9 for $24 \mathrm{~h}(\times 20)$

uses. The results provide information that electrolyzed water has antibacterial, cytotoxic, and antioxidant activities. The activity is dependent on $\mathrm{pH}$. The electrolyzed water at $\mathrm{pH} 2.5$ showed the highest antibacterial activity. The alkaline electrolyzed water showed the highest cytotoxicity on T47D cell lines, with an $\mathrm{IC}_{50}$ of $46.6 \%$. Furthermore, the electrolyzed water showed free radical scavenging activity with an $\mathrm{EC}_{50}$ of $167.6 \%$ at $\mathrm{pH} 9.5$.

\section{CONFLICTS OF INTEREST}

The authors declare that they have no conflicts of interest.

\section{ACKNOWLEDGMENT}

The authors are highly grateful to financial support from LPPM Universitas Muhammadiyah Purwokerto.

\section{REFERENCES}

1. Ignatov I, Gluhchev G, Karadzhov S, Miloshev G, Ivanov N, Mosin O. Preparation of electrochemically activated water solutions (catholyte/ anolyte) and studying their physical-chemical properties. J Health Med Nurs 2015;13:64-78.

2. Rahman SM, Khan I, Oh DH. Electrolyzed water as a novel sanitizer in the food industry: Current trends and future perspectives. Compr Rev Food Sci Food Saf 2016;15:471-90.

3. Sharma RR, Demirci A. Treatment of Escherichia coli O157:H7 inoculated alfalfa seeds and sprouts with electrolyzed oxidizing water. Int J Food Microbiol 2003;86:231-7.

4. Bari ML, Sabina Y, Isobe S, Uemura T, Isshiki K. Effectiveness of electrolyzed acidic water in killing Escherichia coli O157:H7, Salmonella enteritidis, and Listeria monocytogenes on the surfaces of tomatoes. J Food Prot 2003;66:542-8

5. Al Haq MI, Sugiyama J, Isobe S. Review applications of electrolyzed 
water in agriculture and food industries. Food Sci Technol Res 2005;11:135-50

6. Kim MJ, Kim HK. Anti-diabetic effects of electrolyzed reduced water in streptozotocin-induced and genetic diabetic mice. Life Sci 2006;79:2288-92.

7. Ye J, Li Y, Hamasaki T, Nakamichi N, Komatsu T, Kashiwagi T, et al. Inhibitory effect of electrolyzed reduced water on tumor angiogenesis. Biol Pharm Bull 2008;31:19-26.

8. Tsai CF, Hsu YW, Chen WK, Ho YC, Lu FJ. Enhanced induction of mitochondrial damage and apoptosis in human leukemia HL-60 cells due to electrolyzed-reduced water and glutathione. Biosci Biotechnol Biochem 2009;73:280-7.

9. Saitoh Y, Harata Y, Mizuhashi F, Nakajima M, Miwa N. Biological safety of neutral-pH hydrogen-enriched electrolyzed water upon mutagenicity, genotoxicity and subchronic oral toxicity. Toxicol Ind Health 2010;26:203-16.

10. Shirahata S, Kabayama S, Nakano M, Miura T, Kusumoto K, Gotoh M, et al. Electrolyzed-reduced water scavenges active oxygen species and protects DNA from oxidative damage. Biochem Biophys Res Commun 1997;234:269-74.

11. Shirahata S, Hamasaki T, Teruya K. Advanced research on the health benefit of reduced water. Trends Food Sci Technol 2012;23:124-31.

12. Moorman E, Montazeri N, Jaykus LA. Efficacy of neutral electrolyzed water for inactivation of human norovirus. Appl Environ Microbiol 2017;83:e00653-17.

13. Brand-Williams W, Cuvelier ME, Berset C. Use of a free radical method to evaluate antioxidant activity. Lebenson Wiss Technol 1995;28:25-30.

14. Kedare SB, Singh RP. Genesis and development of DPPH method of antioxidant assay. J Food Sci Technol 2011;48:412-22.

15. Nakagawara S, Goto $T$, Nara M, Ozawa Y, Hotta K, Arata Y. Spectroscopic characterization and the $\mathrm{pH}$ dependence of bactericidal activity of the aqueous chlorine solution. Anal Sci 1998;14:691-8.

16. Venkitanarayanan KS, Ezeike GO, Hung YC, Doyle MP. Efficacy of electrolyzed oxidizing water for inactivating Escherichia coli O157:H7, Salmonella enteritidis, and Listeria monocytogenes. Appl Environ Microbiol 1999;65:4276-9.

17. McPherson LL. Understanding ORP's in the disinfection process. Water Eng Manage 1993;140:29-31.

18. Marriott NG, Gravani RB. Principles of Food Sanitation. $5^{\text {th }}$ ed. New York: Springer; 2006.

19. Korting HC, Lukacs A, Vogt N, Urban J, Ehret W, Ruckdeschel G, et al. Influence of the $\mathrm{pH}$-value on the growth of Staphylococcus epidermidis, Staphylococcus aureus and Propionibacterium acnes in continuous culture. Zentralbl Hyg Umweltmed 1992;193:78-90.

20. Sandvik EL, McLeod BR, Parker AE, Stewart PS. Direct electric current treatment under physiologic saline conditions kills Staphylococcus epidermidis biofilms via electrolytic generation of hypochlorous acid. PLoS One 2013;8:e55118.

21. O'Connor PM, Jackman J, Bae I, Myers TG, Fan S, Mutoh M, et al. Characterization of the p53 tumor suppressor pathway in cell lines of the national cancer institute anticancer drug screen and correlations with the growth-inhibitory potency of 123 anticancer agents. Cancer Res 1997;57:4285-300.

22. Blois MS. Antioxidant determinations by the use of a stable free radical. Nature 1958;181:1199-200.

23. Hamasaki T, Harada G, Nakamichi N, Kabayama S, Teruya K, Fugetsu B, et al. Electrochemically reduced water exerts superior reactive oxygen species scavenging activity in HT1080 cells than the equivalent level of hydrogen-dissolved water. PLoS One 2017;12:e0171192.

24. Pisoschi AM, Negulescu GP. Methods for total antioxidant activity determination: A review. Biochem Anal Biochem 2011;1:1000106. 